\title{
Błądzenie Michałka. Nad mapą Warszawy Prusa
}

Wojciech Tomasik 


\section{Przechadzki}

\section{Błądzenie Michałka. Nad mapą Warszawy Prusa}

Wojciech Tomasik

TEKSTY DRUGIE 2017, NR 5, S. 313-329

DOI: $10.18318 / \mathrm{td} .2017 .5 \cdot 21$

$M$ ichałko to opowiadanie o człowieku innym, o bohaterze, który zdradza swą inność już po paru chwilach kontaktu. Jego dziecięca naiwność rzuca się w oczy nawet prostym robotnikom najemnym: chłopak jest dla nich „durnym Michałkiem”. Bohater spotęguje swą inność, gdy postawi stopę w wielkim mieście, gdy - za namową życzliwego inżyniera - z nader skromnymi funduszami pojedzie tam, dokąd zaprowadzą go szyny ukończonej właśnie kolei. Warszawa usłyszy, że Michałko mówi „śpiewającym głosem” (573)², miasto stanie się zaś dla bohatera przestrzenią obcą, nieprzyjaznym labiryntem. Doświadczenie Michałkowej dezorientacji zrozumie najlepiej ktoś, kto o topografii miasta ma dobre pojęcie. Michatko to nowela wybitnie warszawska. Nie tylko z tej racji, że jej akcja toczy się właśnie w Warszawie, także
Wojciech

Tomasik - prof.

dr hab., kierownik

Katedry Kultury

Współczesnej UKW

w Bydgoszczy.

Ostatnio publi-

kował: Pociag do

nowoczesności. Szkice

kolejowe (2014), Ikona nowoczesności. Kolej

w literaturze polskiej

(wyd. 2: 2015), Szalony

bieg. Kolej i ciemna

nowoczesność (2015).

Kontakt:woj55@

poczta.onet.pl

1 Wszystkie cytaty z noweli Michałko są lokalizowane w tekście głównym. Pochodzą one z wydania: B. Prus Pisma wybrane, wstęp M. Dąbrowska, t. 1: Nowele, PIW, Warszawa 1990. Liczba podana w nawiasie oznacza numer strony. 
dlatego, że jej założonym czytelnikiem ma być ktoś, kto w tym mieście umie się poruszać, ktoś, kto w Warszawie na stałe mieszka lub często w niej przebywa. Błądzenie Michałka, w którym wyraża się jego inność, przemówić miało do czytelnika-warszawiaka i to najpewniej do kogoś z tych lepszych, zamożniejszych dzielnic. Michałko wyszedł w 1880 roku w felietonowych porcjach, którym miejsca użyczył poczytny „Kurier Warszawski”. Miał przemawiać przede wszystkim do prenumeratorów tego dziennika, miał apelować do ludzi dobrego serca, których reprezentuje w utworze ów pan, co to - poruszony wyglądem zmizerowanego i przemokniętego Michałka - „dał mu złotówkę i odszedł mrucząc" (582). Dezorientacja bohatera nie może udzielać się czytelnikowi. Gdy Michatko przestał trafiać do odbiorców mających szansę, by spotkać na ulicy tytułowego bohatera, gdy nowela stała się częścią literackiej przeszłości, potrzebny stał się ktoś, kto zamknięty w utworze świat zrekonstruuje, wykreśli mapę nieistniejącego już miasta, pokaże miejsca, których nie mógł rozpoznać prostoduszny przybysz z prowincji. Błądzenie Michałka to wyzwanie dla dzisiejszego historyka literatury. Nie jest to bynajmniej wyzwanie największe, bo i utwór do największych nie należy, ale wydaje się ono ważne zwłaszcza wtedy, gdy ma się w perspektywie zadania ambitniejsze zbadanie mapy Warszawy, która odsłania się w Lalce, i prześledzenie drogi, jaka zaprowadziła Prusa do topograficzno-kalendarzowej maestrii, o jakiej ta wielka powieść zaświadcza ${ }^{3}$.

Michałko sprawia współczesnemu literaturoznawcy kłopot również dlatego, że nowela wymyka się poetyce klasycznego realizmu. Historię chłopskiego sieroty poznaje tutaj czytelnik z ust narratora, który swą perspektywę poznawczą przez znaczną część utworu synchronizuje z mentalnością niepiśmiennego i zahukanego chłopaka. Spersonalizowana narracja sprawia, że widzimy to, co dostrzec może „durny Michałko". I wiemy to, czego dowiadywał się Michałko dzięki życzliwości ludzi, których zdołał poruszyć swoim losem. Nowela zaczyna się in medias res, w fikcyjny świat wchodzi się zdaniem zwyczajnym, którego kształt w zupełności odpowiadał kompetencjom

2 Zob. "Kurier Warszawski” $1880 \mathrm{nr}$ 234-236.

3 Zob. Śladami Wokulskiego. Przewodnik literacki po warszawskich realiach "Lalki", książkę skomponował, opatrzył wstępem i posłowiem L.B. Grzeniewski, Czytelnik, Warszawa 1957; L.B. Grzeniewski Warszawa w "Lalce" Prusa, PIW, Warszawa 1965. Badaniu "geografii literatury" (i "mapowaniu" XIX-wiecznych utworów powieściowych) nowy impuls nadała książka: F. Moretti Atlas of the European Novel 1800-1900, Verso, London 2015 (pierwodruk włoski: 1997). Śledząc ", błądzenie" Prusowego bohatera, wykorzystuję przede wszystkim inspiracje, jakie daje rozdział 2: A tale of two cities 
poznawczym bohatera: „Roboty przy kolei skończono” (570).Zdanie to, rozpaczliwie proste, nabierze zaprojektowanego przez pisarza sensu, gdy czytelnik wzniesie dla niego czasowo-przestrzenny kontekst, gdy rzutuje zdarzenie fikcyjne na mapę prawdziwą, a pospolite słowo „kolej” podmieni na historyczną nazwę własną. Jaką zatem kolej skończył budować nasz bohater, jakie wydarzenie ze świata prawdziwego uznać wolno za punkt otwierający ciąg jego przygód? W pytaniu o miejsce i historyczną tożsamość inicjalnego zdarzenia (zakończenia robót przy kolei) zawarte jest też pytanie o czas: kiedy zaczynają się perypetie Michałka? Jak czas fikcyjnych zdarzeń sytuuje się względem czasu, w którym żyli prawdziwi prenumeratorzy „Kuriera Warszawskiego" i w którym dowiadywali się z felietonowych kawałków o Michałkowych perypetiach? Czy były szanse, by „kurierowi” czytelnicy spotkali na swej drodze kogoś, kto miałby rysy „durnego Michałka” i komu mogliby pospieszyć z pomocą? A zatem: kiedy toczy się akcja noweli? Czy czas fikcyjny jest skorelowany z pozaliterackim? W Lalce ta korelacja osiąga próg doskonałości. Jak sprawy się mają w opublikowanym parę lat wcześniej Michatku?

Kwestię wywoływanych tutaj czasowo-przestrzennych koordynat noweli podjął Stanisław Fita, charakteryzując związki biografii i twórczości Prusa z Warszawą. I napisał:

Michałko przybył raczej na dworzec Kolei Terespolskiej (dziś Warszawa Wschodnia) przy ówczesnej ulicy Wołowej. Gdy bowiem po krótkim okresie pracy na budowie w pobliżu dworca udał się do Warszawy w poszukiwaniu lepszego zarobku, droga do mostu zajmuje mu dużo czasu. W Michałku występuje, rzadko pojawiające się w utworach pisarza, tło Pragi oraz nowych dzielnic rozbudowującego się miasta. ${ }^{4}$

Pójdźmy za Fitą, podstawmy zatem historyczne konkrety i sprawdźmy, do czego taka operacja nas doprowadzi. Jeśli podróż Michałka miałaby swój finał na dworcu kolei Terespolskiej, to zakończenie robót, o którym mowa w pierwszym zdaniu noweli, przenosiłoby czytelnika do września-października 1866 roku, bo właśnie wtedy gotowy był odcinek torów łączący Siedlce z ulokowaną przy ulicy Wołowej na Pradze końcową stacją magistrali. Rok później, w połowie września 1867 roku, gotowy był cały szlak, prowadzący z Pragi przez Siedlce i Łuków do Terespola. I właśnie wtedy można byłoby

4 S. Fita Bolesław Prus, w: Warszawa pozytywistów, red. J. Kulczycka-Saloni, E. Ihnatowicz, ILPU, Warszawa 1992, s. 128. 
powiedzieć tak, jak rozpoczyna swą opowieść narrator Michatka: „Roboty przy kolei skończono". Czyżby zatem fikcyjna podróż Michałka miała się zacząć gdzieś w okolicach prawdziwego Terespola? Nic nam o tej podróży nie powie jedyna nazwa, która się do niej odnosi, mijane po drodze rodzinne Wilczołyki są bowiem niewątpliwie nazwą fikcyjną. Nasz bohater jest niepiśmienny, nie możemy przeto oczekiwać, by łowił wzrokiem nazwy wymalowane na stacyjnych budynkach. Po drodze znajduje się jedno większe miasto: wiemy, że jest ono bardzo oświetlone (roboczy pociąg z Michałkiem dociera do niego nocą) i że leży na wzgórzu. Wilczołyki Michałka ulokowane są z pewnością gdzieś na wschodzie, gdyż zdradza to bohater melodyką głosu; o okolicy, gdzie kolejowe roboty skończono, dowiadujemy się, że jest bagienna i płaska, ale w drodze do Warszawy szybko ustępuje miejsca terenom pagórkowatym, poprzecinanym bystro płynącymi rzeczkami. Czyżby uprawniony stał się wniosek, który zasugerował Fita - mianowicie, że Michałko dociera do stacji na Pradze świeżo pobudowaną koleją Terespolską, gdzieś z początkiem września 1867 roku?

We wrześniu 1867 roku na Pradze działały dwa dworce: starszy, obsługujący kolej Warszawsko-Petersburską, i nowy, wzniesiony dla potrzeb kolei Warszawsko-Terespolskiej. O tym pierwszym dostaje czytelnik drobną wzmiankę: okazuje się bowiem, że stróż, który nie chce wpuścić Michałka na nocleg do niewykończonego budynku, pochodzi, jak z dumą mówi, „nie ze wsi, ino z miasta... Z Łapów! [...]" (583). Michałko nie wie, rzecz jasna, że Łapy nie są żadną metropolią, nie wie też (inaczej niż „kurierowy” czytelnik), że z „Łapów” ściągali do Warszawy ludzie szukający pracy, a przyjeżdżali tu, wykorzystując otwartą w grudniu 1862 roku kolej Warszawsko-Petersburską. Oba wspomniane dworce zjawiają się w jeszcze jednym miejscu noweli, gdy zdesperowany Michałko, oszukiwany i poszturchiwany na budowach, postanawia wracać do domu, i gdy zaczyna w Warszawie szukać kolei, którą jakiś czas temu do miasta przyjechał. Pyta zatem przechodniów o drogę:

Idąc za ich wskazówkami trafił na kolej, ale - nie swoją.

Zobaczył jakąś stację wielką, ludną i pełno domów wkoło niej, a szyn ani śladu.

Zmieszał się bardzo i zląkł nie wiedząc, co się stało. Aż mu dopiero jakaś litościwa dusza wytłomaczyła, że są jeszcze trzy inne koleje, ale - za Wisłą. (582)

Te „trzy inne koleje” miały swoje stacje: dwie z nich zostały już wspomniane przeze mnie, to Dworzec Petersburski i Dworzec Terespolski. Współczesny 
Prusowi czytelnik-warszawiak (i prenumerator „Kuriera Warszawskiego”) wiedział, że, kierując się wskazaniami uczynnych przechodniów, Michałko dotarł był do stacji kolei Warszawsko-Wiedeńskiej (na skrzyżowaniu Alei Jerozolimskich i ulicy Marszałkowskiej), wokół której dostrzegł "pełno domów [...], a szyn ani śladu". Warszawa z Michałka ma zatem łącznie cztery dworce (jeden w samym mieście i trzy za Wisłą, na Pradze), które służyły czterem różnym przedsiębiorstwom kolejowym. Stacja, do której dotarł Michałko, leży w okolicy pustej (bohater w jej otoczeniu wielu domów nie dostrzegł), była dość prymitywnie urządzona, skoro - inaczej niż na dworcu Warszawsko-Wiedeńskim - z zewnątrz widziało się tam szyny. Akcja noweli toczyć się zatem musi w Warszawie, której potrzeby komunikacyjne zaspakajały trzy prawobrzeżne stacje i trzy przybiegające do nich drogi żelazne. A to oznacza, że czas historyczny Michałkowych przygód przesunąć trzeba na sierpień-wrzesień 1877 roku. Bohater przyjechał pociągiem roboczym nie na dworzec Terespolski, lecz na Pragę (Nadwiślańską)5. Uroczyste oddanie do użytku publicznego Drogi Żelaznej Nadwiślańskiej (biegnącej od Mławy przez Pragę i Lublin do Kowla) nastąpiło 29 sierpnia 1877 roku. Michałko dotarł do Pragi kilkanaście dni wcześniej.

O praskiej stacji kolei Nadwiślańskiej, tej, która przywitała Michałka, pisało się jeszcze przed jej otwarciem - dużo i źle. Do chóru krytycznych głosów dołączył też Bolesław Prus. Ten prasowy akompaniament dawał czytelnikowi wiedzę, do której pisarz, opowiadając historię Michałka, mógł się odwoływać. Dziś tę wiedzę historyk literatury musi cierpliwie rekonstruować, wydobywając ze stron warszawskich dzienników i tygodników klimat rozczarowania, który gęstniał wraz z tym, jak zbliżała się finalizacja wielkiej inwestycji. Bo kolej Nadwiślańska już na etapie projektowania wyraźnie manifestowała, że ma służyć do obsługi rozlokowanych na linii Wisły rosyjskich twierdz, że normalne przewozy pasażerskie będą dla niej tylko uzupełnieniem jej militarnego przeznaczenia. Dobitną zapowiedzią tego, że w wytyczaniu kolei Nadwiślańskiej względy militarne biorą górę nad interesem mieszkańców, było oddanie do użytku tzw. kolei obwodowej, która zapewniała połączenie szerokotorowej sieci kolejowej z prawego brzegu Wisły z, trzymającą się zachodnioeuropejskiego (standardowego) rozstawu szyn, drogą żelazną

5 Dziś na miejscu dworca Praga (Nadwiślańska) rozlokowany jest niepozorny przystanek kolejowy Warszawa Praga. Podjazd pod dawną stację i budynek dworca znajdował się po zachodniej stronie torów. Nieliczne pozostałości po infrastrukturze stacji Praga Nadwiślańska są w stanie kompletnej ruiny. 
Warszawsko-Wiedeńską. Budowa kolei obwodowej wymagała przerzucenia przez Wisłę mostu w rejonie cytadeli. Dwupoziomową konstrukcję zaprojektowano w ten sposób, że jej górny poziom pełnił funkcję przeprawy kolejowej, natomiast dolny przystosowany był do ruchu pojazdów i pieszych. Ponad dwa lata po uruchomieniu mostu felietonista „Kuriera Warszawskiego" pisał z goryczą:

Na czym jednak grubo zawiedliśmy się, to na moście budowanym około cytadeli w celu połączenia kolei Nadwiślańskiej z drogą obwodową. Przypuszczaliśmy, a zdaje się nawet bardzo racjonalnie, iż tak kosztowne dzieło - choć głównie przedsięwzięte dla specjalnego celu - nie będzie, nie może nawet, nie oddać ważnych dla grodu naszego usług. Inaczej się jednak stało. Most od dwóch lat ukończony służy wyłącznie dla drogi żelaznej; miasto żadnego nie ma z niego użytku, choć przy dzisiejszym rozwoju Pragi, przeważnie w przemysłowym kierunku, jeden most nie wystarcza potrzebie. Czy to zamknięcie dla publiczności nowego mostu jest czasowe tylko - nie wiemy, choć zbudowany on jest na szerokość taką, iż dwa wozy podobno minąć się nie mogą. ${ }^{6}$

$\mathrm{Na}$ otwarcie „dla publiczności” mostu przy cytadeli i na rozluźnienie tłoku na moście przy Zamku Warszawa czekała jeszcze prawie dwa lata7.

6 J.K. Cyferka Nadesłane , "Kurier Warszawski” 1879 nr 11 (z 4 [16] stycznia). O ukończeniu budowy i rychłym uruchomieniu dla kolei mostu pod cytadelą donosiła prasa już w 1875 roku: „Wczoraj około godziny 12 JW. Minister Komunikacji zwiedzał nowy most pod cytadelą, oglądał go bardzo szczegółowo, przejechał wagonem ciągnionym przez lokomotywę, po czym taż lokomotywa przebiegała most z szybkością 60 wiorst na godzinę. Minister objawił żywe zadowolenie z budowy. Słyszeliśmy, że otwarcie eksploatacji nowego mostu nastąpi już podobno około 1 sierpnia" (Nowy most, "Gazeta Warszawska" 1875 nr 143, z 21 czerwca/3 lipca). Do otwarcia mostu dla potrzeb kolei obwodowej doszło dopiero w połowie listopada 1876 roku.

7 Stało się to dopiero w 1880 roku i - nie bez oporów. Już w styczniu pojawiały się pierwsze zapowiedzi udostępnienia mostu wszystkim: „Przejazd przez most pod cytadelą, dotychczas dozwolony jest tylko dla wojsk, a kwestia otwarcia przejazdu dla wozów włościańskich, których nagromadzenie na moście obok Zamku utrudniało komunikację szczególniej w dni targowe, kilkakrotnie już podnoszoną była. Obecnie, jak donosi jedno z pism, pan Minister Komunikacji zezwolił w zasadzie na przepuszczanie wozów przez most pod cytadelą". Dalej mowa jest o projektowanym ruchu wahadłowym i uciążliwościach takiej organizacji ("Gazeta Handlowa” $1880 \mathrm{nr}$ 2, z 17 [29] stycznia). Jeszcze późną jesienią most nie był otwarty, jak wynika to z następującej informacji: „Most żelazny pod cytadelą ma być w przyszłym tygodniu otwartym dla komunikacji publicznej” („Wiek” 1880 nr 249, z 27 października/8 listopada). Otwarcie nastąpiło w grudniu. 
Enigmatyczne sformułowanie mówiące o dziele przedsięwziętym „dla specjalnego celu" znaczyło po prostu, że most przy cytadeli miał służyć wyłącznie do przemieszczania się kolumn wojskowych. Michałko, wybierając się z Pragi do Warszawy, musiał nadkładać drogi. Co ciekawe: most przy cytadeli, doskonale widoczny z jedynej działającej przeprawy przy Zamku, w ogóle nie zwrócił uwagi naszego bohatera...

Podróż Michałka do miasta kończy się na stacji, o której w noweli mamy dość skąpe informacje. Prawie wszystko mieści się w następującym urywku:

Stacja. Michałko wysiadł. Pocałował brekowego w rękę i rozejrzawszy się poszedł z wolna do sklepu, gdzie na szyldach wymalowane były kufle z czerwonym piwem i zielona wódka we flaszkach. [...] Za szynkiem widać było murujący się dom, a przed sklepem stali mularze. $(573)^{8}$

Prus miał pewność, że ta skąpa charakterystyka czytelnikowi „Kuriera” w zupełności wystarczy do zlokalizowania miejsca zdarzeń na mapie Warszawy: rzecz dzieje się na stacji Praga Nadwiślańska, położonej na obszarze folwarku Pelcowizna, na terenie, który wcześniej nie nosił żadnych śladów miejskiej infrastruktury. Kluczowa informacja to ta, że wokół stacji wznoszone są nowe domy, że Michałko wysiadł z pociągu w miejscu, które - używając języka z innej epoki - było prawdziwym zagłębiem budowlanym. Jeszcze w styczniu 1876 roku w materiale z "Wieku” można było przeczytać, że na tle ożywienia w budownictwie, jakie obserwuje się w Warszawie, bardzo blado przedstawia się sytuacja na Pradze - „której mieszkańcy aż dotąd tradycjonalnie usiłują przechowywać swe przedmiejskie poglądy, uprzedzenia, zwyczaje i obyczaje". I o ile miejscowości, które przylegały do linii Warszawsko-Wiedeńskiej, „zabudowały się okazale”, to na Pradze podobne ożywienie nie nastąpiło'. Już jednak pod koniec 1877 roku, w czasie, gdy działać zaczynała kolej Nadwiślańska, ta sytuacja radykalnie się zmieniała. Warszawiacy dowiadywali się teraz ze swojego „Kuriera”: „Pelcowizna traci po trosze charakter... pustki. W niewielkiej odległości od warsztatów [mechanicznych] stanęło już kilka domów, między którymi są nawet i piętrowe". Ożywieniu budowlanemu towarzyszyła zwyżka cen gruntów: jeszcze

8 "Prawie wszystko", bo nim bohater wysiadł na Pradze, usłyszał od inżyniera: " - Tam zaraz przy stacji budują nowe domy. Będziesz nosił cegłę i nie umrzesz z głodu, byłeś się nie rozpił" (572).

9 Zob. k. „Wiek" 1875/1876 nr11, z 30 grudnia/11 stycznia. 
w lipcu 1877 roku za łokieć kwadratowy płaciło się tutaj 15 kopiejek, zaś już w listopadzie $-30^{10}$.

Stacja Praga Nadwiślańska, nim jeszcze powstała, miała w Warszawie złą prasę. Powód był bardzo oczywisty: folwark Pelcowizna, gdzie była budowana, leżał w znacznej odległości od Warszawy, a most przy cytadeli, który mógłby warszawiakom skracać dojazd na stację, pozostawał niedostępny. Od początku zatem, tj. od momentu, gdy znane stały się plany lokalizacji praskiej stacji, odzywał się chór głosów krytycznych, który wzmagał się w miarę tego, jak plany przeradzały się w widoczne już obiekty ${ }^{11}$. Z odległej lokalizacji niemiłosiernie drwiono:

Jesteśmy na Pelcowiznie... A wiecie wy czytelnicy co to jest Pelcowizna? O! - to miejscowość dziś tak ważna, jak ważnym jest dla ogółu publiczności pytanie, gdzie będzie w Warszawie pomieszczoną stacja Nadwiślańskiej kolei. [...] Na Pelc...co...wiznie? Powtórzyła ze zdziwieniem publiczność, a gdzież to jest Pelcowizna owa? Jest blisko dwie wiorsty za Petersburską rogatką, a blisko sześć wiorst odległą od środka miasta. [...] Bez względu bowiem na sarkanie powszechne, na głos prasy, na obliczanie wreszcie olbrzymich kosztów, jakie publiczność będzie musiała ponosić chcąc się dostać na parę wiorst za jedne z najbardziej od środka miasta oddalonych rogatek - dworzec nowej kolei staje, jak wspomnieliśmy, na Pelcowiznie i... basta. I dlaczego?, pytamy kompetentnych techników. Tak „wypadło z niwelacji” - odpowiadają nam panowie ci z pewną siebie powaga. ${ }^{12}$

Ten mocno krytyczny ton nieco łagodzić mogły doniesienia, że „publiczność" warszawska, chcąca skorzystać z nowej kolei, będzie mogła liczyć na dowiezienie do nowej stacji pociągiem odchodzącym z dworca Warszawsko-Wiedeńskiego i korzystającym z gotowej linii obwodowej. Bardzo wcześnie pojawiły się też zapowiedzi, że na linii obwodowej, w bezpośrednim sąsiedztwie cytadeli, uruchomiony zostanie nowy warszawski dworzec, do

Zob. [notka], „Kurier Warszawski” 1877 nr 257, z 8 (20) listopada.

„Kwestia banhofu drogi Nadwiślańskiej na stacji Warszawa, jak słyszeliśmy, została już podobno stanowczo zdecydowaną w sposób taki, że dworzec i biura stacyjne mają stanąć na gruntach folwarku Pelcowizna, w odległości kilku wiorst od miasta” ("Wiek" 1875 nr 220, z 24 września/6 października).

Q. „Wiek" 1876 nr 118, z 18 (30) maja. 
którego dotrzeć będzie można z miasta znacznie łatwiej. Pisano również, że ten nowy dworzec będzie miał najpewniej także charakter "tymczasowy”, ponieważ w przyszłości odprawa pasażerska odbywać się będzie na dworcu znajdującym się w bezpośrednim sąsiedztwie tego, który od ponad trzech dekad służył kolei Warszawsko-Wiedeńskiej' ${ }^{13}$ W lutym 1878 roku kolej Nadwiślańska faktycznie otworzyła dla swoich klientów stację na przedpolu cytadeli (przy ulicy Zakroczymskiej) ${ }^{14}$. Do planowanego przeniesienia tej stacji w sąsiedztwo dworca kolei Warszawsko-Wiedeńskiej nigdy jednak nie doszło.

W chórze krytycznych głosów o zlokalizowanej na Pelcowiznie stacji wybijał się Bolesław Prus. W felietonie z cyklu Kartki z podróży część temu poświęcona została zapowiedziana formułą: „O stacji, na której nie umieją uszanować ludzi znakomitych". A charakterystyka nowego obiektu spoczywa na następującym fragmencie:

Warszawska stacja drogi Nadwiślańskiej wybudowana jest z drzewa i pomalowana na piękny choć melancholiczny kolor szary. Struktura jej przypomina domek szwajcarski w stylu chińskim, a dwie frontowe wieżyczki wiele mówią o guście artysty, który plan budynku nakreślił. Wnętrze jednak zdaje się być obszerne i wygodne, szczególniej dla tych, którzy jak ja, mają zwyczaj przepędzać czas na dworze, a przymioty kobiet i zalety wszelkich instytucji publicznych podziwiać przez okno.

Ponieważ linia nadwiślańska znajduje się w kolebce, więc do stacji można jeszcze dojechać z Warszawy za rubla i 50 kopiejek. Obawiam się jednak, aby z czasem podróżni nie potrzebowali zadawać sobie pytania: czy jazda doróżką do kolei a potem koleją do Mławy, czy też jazda wprost do Mławy doróżką? Dużo się wprawdzie pisało o wybudowaniu w War-

13 Zob. Droga Nadwiślańska, "Gazeta Handlowa” 1877 nr 191, z 18 (30) sierpnia; W sprawie banhofu kolei Nadwiślańskiej, „Wiek” 1878 nr 21, z 13 (25) stycznia.

14 O rozpoczęciu budowy dworca donosił „Kurier Warszawski” w 1877 nr 177, z 26 lipca/7 sierpnia. Odprawienie pierwszego pociągu kwitował ten dziennik z początkiem 1878 ( $\mathrm{nr}$ 36, z 1 [13] lutego). Dziś na tym miejscu znajduje się stacja Warszawa Gdańska. Z dość skomplikowanym układem XIX-wiecznych dworców warszawskich nie poradzili sobie redaktorzy tomu Warszawa pozytywistów. W Indeksie ulic, miejsc i budynków w Warszawie (sporządzonym przez Agnieszkę Pliszkiewicz; zob. Warszawa pozytywistów, s. 277) mamy hasło: „Dworzec Kolei Warszawsko-Wiedeńskiej (dziś Warszawa Gdańska)". Informacja w nawiasie winna towarzyszyć innemu hasłu - „Dworzec Kolei Nadwiślańskiej”. 
szawie centralnego dworca dla wszystkich dróg żelaznych dotykających miasta, a także o przeniesieniu stacji kolei Nadwiślańskiej do bardziej ucywilizowanego punktu. ${ }^{15}$

W tym miejscu relacji rolę korespondenta porzuca Prus dla roli satyryka i pisze, że lokalizacja dworca na Pradze to znak, że zarząd kolei Nadwiślańskiej „nie czytuje naszych dzienników”. Także zdanie o przeniesieniu stacji do „bardziej ucywilizowanego punktu” musiało dla kierownictwa „Kuriera” zabrzmieć polityczną nutą, skoro zdecydowało się ono dodać do zdania odsyłacz i w stosownym przypisie złagodzić szorstkość Prusowych opinii:

Wiadomo nam, że dla udogodnienia podróżnym komunikacji tworzyły się różne projekty. Komunikacja ta najskuteczniej może być zapewnioną za pośrednictwem istniejącej już kolei obwodowej. Dotychczas, o ile wiemy, ze wszystkich tych projektów utrzymał się jeden tylko, zbudowania pośredniego dworca wprost ulicy Zakroczymskiej. Głównie idzie o to, ażeby podróżni nie byli zmuszeni do ciągłego przesiadania się wraz z bagażami. Niewygody tej jak dotychczas nawet przy nowym dworcu trudno będzie uniknąć, zawsze jednakże komunikacja znacznie ułatwioną zostanie. $^{16}$

Prus kierował swego Michałka do tych, którzy mieli w żywej pamięci to, co wypełniało początek jego relacji z podróży do Ciechanowa. Pisarz z Pragi Nadwiślańskiej wyjeżdżał, jego bohater tutaj przyjechał. Obie te podróże łączyła ważna okoliczność. Obie (prawdziwa i fikcyjna) odbyły się przed oficjalnym otwarciem nowej kolei, w ramach jazd próbnych.

Prus szczędzi czytelnikowi informacji o dacie wyjazdu, ale wszystko wskazuje na to, że doszło do niego parę dni przed publikacją Kartek z podróży, czyli gdzieś na samym początku sierpnia 1877 roku. Linia kolei Nadwiślańskiej budowana była równocześnie na całej jej długości (tj. od Mławy przez Pragę i Lublin do Kowla, wraz z odnogą z Iwangrodu [Dęblina] do Łukowa), poszczególne jej odcinki gotowe były w różnym czasie, normalna jej eksploatacja zaczęła się dopiero 29 sierpnia 1877 roku. Na otwarcie czekano z wielką niecierpliwością. Na niektórych odcinkach próbne przejazdy odbywały się już kolejne cytaty będą pochodziły z tego czasopiśmiennego wydania.

16 Tamże (Przypisek Redakcji).
} 
w 1876 roku ${ }^{17}$, otwarcie całości hamowały jednak wielkie przeprawy mostowe, przede wszystkim ta na Narwi, zlokalizowana w bezpośredniej bliskości twierdzy w Nowogeorgiewsku (Modlinie), niedaleko „dworca wojennego", oraz ta na Wieprzu pod Iwangrodem (Dęblinem). Most pod twierdzą nowogeorgiewską był gotowy wcześniej, ten pod twierdzą iwangrodzką ukończony został dopiero w połowie sierpnia. To oznaczało, że w początkach sierpnia 1877 roku zarząd kolei Nadwiślańskiej mógł zorganizować dla przedstawicieli warszawskiej prasy przejazd promocyjny (tak byśmy go dziś nazwali) do Mławy ${ }^{18}$. Wiele wskazuje na to, że Prus złożył do „Kuriera” swoją relację z podróży do Ciechanowa, którą odbył w ramach takiego „przejazdu dla prasy", a w każdym razie - próbnego przejazdu nową linią, zorganizowanego tylko dla wybranych. Przypomnijmy niektóre szczegóły z Prusowej relacji. Pisarz z przyjacielem znalazł się na stacji „już o godzinie 8", nigdzie jednak nie znajdujemy wzmianki o rozkładzie jazdy, któremu podporządkowana byłaby ta pora przybycia ${ }^{19}$. Mowa jest za to o tym, że około godziny 10 dorożka przywiozła z Warszawy znajomego dziennikarza, „który miał ostatecznie sprawdzić i usankcjonować fakt istnienia drogi Nadwiślańskiej". Na peronie nie widać podróżnych, są za to robotnicy („tapicerowie”), którzy „obijali ceratą długie stoły”. W pociągu, który ruszył, „odbywała się jakaś sesja techniczna", co sygnalizował szczęk widelców i pukanie korków. Na stacjach na

17 W końcu marca 1876 roku gotowe było m.in. połączenie kolei obwodowej ze stacją Praga Nadwiślańska (zob. [notka], „Wiek" 1876 nr 72, z 19 [31] marca).

1810 sierpnia 1877 roku „Gazeta Warszawska” informowała: „Termin otwarcia kolei [Nadwiślańskiej] jest już bardzo bliski, komisja bowiem delegowana do przyjęcia drogi, ukończyła dnia 9 bm czynności i na podstawie sprawdzenia stanu drogi postanowiła odnieść się niezwłocznie do ministerium komunikacji o upoważnienie do natychmiastowego oddania drogi do użytku publicznego" (Kolej Nadwiślańska , "Gazeta Warszawska” 1877 nr 175, z 29 lipca/10 sierpnia). Niewykluczone, że podróż Prusa odbyła się w ramach jazd komisji, oddelegowanej do "przyjęcia drogi". Prawdopodobnie jazdę próbną utrwala szkic Z okna wagonu od Warszawy do Kowla, sygnowany K.F. (zob. „Kurier Warszawski” 1877 nr 174, z 28 lipca/9 sierpnia). O jednej z takich jazd próbnych mowa jest też w materiale, który wydrukowała "Gazeta Warszawska". Odbyła się ona "ekstrapociągiem dyrektorskim", który 24 sierpnia przejechał z Pragi do Lublina. „Pociągiem tym [...] jechał zarząd drogi, składający się z dyrektora, jego pomocnika, budowniczego etc. i zajmował się głównie oglądaniem stacji i innych budowli przed otwarciem drogi do użytku publicznego. We czwartek osoby prywatne jechać nie mogły, bo przewożono wojsko" (Kolej Nadwiślańska, "Gazeta Warszawska" 1877 nr 189, z 16 [28] sierpnia).

19 Warto wspomnieć, że służbowe rozkłady jazdy kolei Nadwiślańskiej (podobnie jak rozkłady służbowe innych kolei z prawego brzegu Wisły) respektowały czas petersburski, publiczne zaś - czas warszawski (cofnięty względem pierwszego o 37 minut). Trudno mi orzec, co podczas wyprawy do Ciechanowa wskazywał zegarek Prusa. 
przyjazd pociągu czekają pracownicy kolejowi; wszędzie powtarza się ten sam scenariusz:

Naraz z pociągu wychodzi osoba trzymająca w ręku stos różnokolorowych oficjalnych czapek, z których jedna po kilku mniej udanych próbach osadza się na głowie przyszłego zawiadowcy, jego pomocnika albo telegrafisty. ${ }^{20}$

Mały bohater przyjechał na Pragę „roboczym pociagiem”. Wyjechał gdzieś ze wschodniego krańca linii, około południa - po skończeniu robót i po ostatniej wypłacie. Do podjęcia decyzji zachęcił go litościwy inżynier. Po przejechaniu mili pociąg roboczy minął wieś Michałka (czytelnik dowie się później, że to Wilkowyje). Dalsza podróż przynosi zmianę krajobrazu. W mijanych wsiach widać też większy dostatek. Michałko pilnie obserwuje: „Znikły kurne chaty i stodoły plecione $\mathrm{z}$ wici, a ukazały się piękne dwory i murowane budynki, lepsze niż u nich kościoły - albo karczmy" (571). Dłuższy postój pociągu przypada na noc:

Nocą stanęli pod miastem zbudowanym na górze. Zdawało się, że domy włażą jeden na drugi, a w każdym tyle światła, co gwiazd na niebie. $\mathrm{Na}$ stu pogrzebach nie zobaczyłby tylu świec, co w tym mieście...

Grało coś bardzo pięknie, ludzie chodzili tłumem śmiejąc się i rzechocząc, choć już była taka noc wielka, że we wsi słyszałbyś tylko wołanie upiora i ujadanie strwożonych psów (572). ${ }^{21}$

Ze stacji pociąg ruszył - „po kilkugodzinnym postoju, nad ranem [...]” (572). Gdzie była ta stacja? I co oznaczał niezwykły ruch ludzi, którzy nie mogli jeszcze stać się pasażerami? Mijanym miastem jest niewątpliwie Lublin, miasto górujące nad stacją, ulokowaną na jego dalekim przedmieściu (Piaskach) ${ }^{22}$. A spotkane na stacji tłumy świętujących ludzi świadczyły o tym, że

20 B. Prus, Kartkiz podróży, s. 2.

Utrudniającą orientację Michałka noc zastąpi przy pierwszym kontakcie z Warszawą płachta dymu ("Jak on tam ośmieli się wejść w ten dym?"; 573) koleją Lublin przedstawia się bardzo pięknie. Rozrzucone na wzgórzu, robi wrażenie miasta znacznie większego niż jest rzeczywiście, a wieże i wieżyce kilkunastu kościołów, jakie dotąd miasto to posiada, dopełniają jeszcze owego wrażenia". 
wybudowanie kolei (pierwszej w mieście!) stało się dla lublinian wydarzeniem naprawdę wielkiej wagi ${ }^{23}$.

A jak przedstawia się przyjazd Michałka od strony kalendarza? Prawdziwą drogą żelazną można było dostać się z Pragi do Lublina już 24 sierpnia 1877 roku, ale - jak wiemy - można to było zrobić „ekstrapociągiem dyrektorskim". Kiedy po tej trasie mógł przejechać Michałko? Nie później niż 29 sierpnia (bo tego dnia rozpoczął się normalny ruch na linii) i pewnie nie prędzej niż około 15 sierpnia (bo wtedy gotowy był most pod Iwangrodem). Pierwsza wzmianka, która dawać może orientację kalendarzową, dotyczy temperatury. Michałko nocuje $\mathrm{z}$ „dziewuchą" w domu na Pradze, który muruje. Dziewczyna trzęsie się trochę ze strachu, a trochę z zimna. „Noc była chłodna i wilgotna" (576) - czytamy. Porzuciwszy murarkę na Pradze, Michałko szuka chleba w Warszawie. Tu pracuje czas jakiś, może miesiąc: „W tej fabryce był chłop do jesieni" (580) ${ }^{24}$. Roboty jednak przerwano, ponieważ czytamy - „W końcu września rozpadały się deszcze” (581). Po raz ostatni dostaniemy sygnał kalendarzowy w scenie, gdy zdesperowany Michałko szuka noclegu „przy fabryce”. Bezdusznemu stróżowi (temu „z Łapów”) bohater powie wtedy z żalem: „- Ja tu przecie robiłem całe lato [...]” (583). Fikcyjny kalendarz, jak widać został, dobrze zestrojony z prawdziwym. Michałkowe perypetie zamykają się w dwóch miesiącach; „całe lato” trzeba bowiem rozumieć tak, jak brzmieć ono mogło w ustach niepiśmiennego, gdzie oznacza czas sposobny do wykonywania murarki, porę, gdy jest jeszcze dostatecznie ciepło.

W tle Michałkowych perypetii stoi porządek przyrody, zakotwienie noweli w czasie historycznym dają przede wszystkim działania ludzi. Warszawa z noweli, wzorem tej prawdziwej, przeżywa okres ożywienia budowlanego, doświadczył tego nasz bohater najpierw na Pradze, a potem - gdy skuszony

Miejscowy dziennik tak oceniał doniosłość budowy linii: „Dzień jutrzejszy jest nader ważnym, pierwszorzędne znaczenie mającym w historii rozwoju ekonomii krajowej. [...] W dziejach prowincji naszej otwarcie drogi żelaznej epokę stanowi" ("Gazeta Lubelska” 1877 nr 97, z 17 [29] sierpnia).

24 Słowo "fabryka” jest tutaj ( $\mathrm{i}$ było już w czasach Prusa) semantycznym archaizmem, który znaczył: budowa. W takim znaczeniu znajdziemy go m.in. w następującym zastosowaniu: „Budowniczy podejmujący się kierunku fabryki ma nieodzowny obowiązek złożyć w tej mierze własnoręczne na piśmie oświadczenie swoje Komisarzowi Administracji tego cyrkułu, w którym będzie się będzie wykonywać budowa, a zaś majstrowie mularscy i ciesielscy obowiązani są deklaracje swoje przed tymże Komisarzem do protokołu podawać" ([Zarządzenie policyjne], "Gazeta Warszawska” 1835 nr 119; „Kurier Warszawski” 1836 nr 96). 
perspektywą pracy - przeszedł na lewy brzeg Wisły. W lewobrzeżnej części miasta buduje się więcej, a natężenie robót nie spada, choć pogoda staje się coraz mniej sprzyjająca. Wędrówkom Michałka w poszukiwaniu zajęcia towarzyszy deszcz. Deszcz, który „lał ciurkiem” (584), nadaje prawdziwy smak schronieniu, które chłopak znalazł „przy fabryce”. Ten deszcz nie pozwala o sobie zapomnieć następnego dnia: usłyszawszy huk, Michałko biegnie na miejsce, „poślizgując się i brnąc w kałużach” (584). I właśnie tą gorączką robót, która nie opada mimo oznak nadciągającej jesieni, spina Prus fikcyjne wypadki z planem prawdziwej Warszawy. Realizm noweli płynie z tego, że wymyślone bohaterstwo spełnia się w najzupełniej prawdziwych okolicznościach. Zamykający fabułę wypadek na budowie mógł zdarzyć się w mieście, o którym dzienniki pisały:

Pomimo dżdżystej pory roboty około murowania domów w naszym mieście trwają obecnie w całej pełni. Kilka domów wznosi się nader szybko, jest nawet nadzieja, że budowle rozpoczęte już po kwartale świętojańskim, jeszcze roku bieżącego pod dach zostaną wzniesione. Pośpiech taki wychodzi na szkody przede wszystkim samym właścicielom, którzy opłacać muszą sowicie liczniejszego robotnika, niezbędnego do przeprowadzenia planu szybkiej budowli. Widocznie nawoływanie prasy, aby do robót przystępowano z początkiem wiosny, są głosem wołającego na puszczy. Każdy przecież rozumie, że tak wczesne rozpoczynanie budowli wychodzi na korzyść właścicielowi, przyszłym lokatorom oraz murom samym, schnącym przy robotach porą letnią prowadzonych. ${ }^{25}$

„Kurier Warszawski” widział w jesiennej murarce także ekonomiczny paradoks: „Ruch budowlany, tak dzielnie kwitnący przez całe lato, pomimo niekorzystnych warunków ekonomicznych manifestuje się i obecnie, bez względu na pogodę"26.

Budowle w Warszawie, "Gazeta Handlowa” 1877 nr 207, z 9 (21) września (przedruk: "Gazeta Polska" 1877 nr 208, z 10 [22] września; zob. też: Ruch budowlany w Warszawie, „Kurier Warszawski” $1878 \mathrm{nr} 43, \mathrm{z} 9$ (21) lutego.

[rubryka Wiadomości miejscowe], „Kurier Warszawski” 1877 nr 210, z 13 (25) września. Do wypadków na warszawskich budowach dochodziło wielokrotnie. Późną jesienią 1878 roku zawalił się dom na ul. Wspólnej, a pod jego gruzami śmierć znalazł jeden robotnik (kilkunastu innych zostało rannych); zob. Zawalenie się domu, "Wiek" 1878 nr 268, z 17 (29) listopada; Wypadek, "Gazeta Warszawska" 1878 nr 269, z 17 (29) listopada; Smutny wypadek, "Gazeta Handlowa" 1878 nr 269, z 17 (29) listopada. Temat wypadków przy budowie kilkakrotnie zajmował Prusa-felietonistę. 
Warszawa z Michałka jest miastem z sierpnia-września 1877 roku. Tym samym, którego rysy rozpoznajemy w pierwszych akapitach Kartek z podróży. W Michatku czasowo-przestrzenne koordynaty zdarzeń są doskonale zestrojone z prawdziwymi. A w Kartkach z podróży? Tu podobnego pytania w zasadzie nie powinno się stawiać. Chodzi wszakże o sprawozdanie faktograficzne, którego wierność historycznym realiom składa się na podstawowy wyznacznik gatunkowości. Uważnego czytelnika (tego z czasów Prusa i tego dzisiejszego) zastanowić musi wszakże jeden szczegół. Relacja z kolejowej eskapady do Ciechanowa, przypomnijmy, wyszła w „Kurierze Warszawskim” z datą 7 sierpnia, sama podróż musiała odbyć się parę dni wcześniej. 23 sierpnia 1877 roku „Kurier” donosił: „W dniu dzisiejszym zarząd drogi Nadwiślańskiej otrzymał z Petersburga depeszę upoważniającą go do otwarcia ruchu na całej linii"27. Pierwsze pociągi z pasażerami odjechały z Pragi do Mławy i Kowla 29 sierpnia. W Kartkach z podróży nie ma wzmianki o innych pasażerach, w specjalnym pociągu do Mławy, poza przedstawicielami warszawskiego światka dziennikarskiego, jechali wyłącznie kolejowi oficjele. Wiemy z relacji, że nuda poprzedzająca odjazd popchnęła Prusa do przydworcowej restauracji, gdzie serwowane były „świeże serdelki” i „prawdziwy zagraniczny alasz”. Wcześniej mowa jest o innym sposobie walki z nudą, a mianowicie o badaniu koloru oczu trzech panienek. O tych panienkach dowiadujemy się, że wyjeżdżały do Lublina „z kilkoma tłumoczkami i jednym ojcem". Skąd wzięły się na peronie te trzy panienki? Rzecz dzieje się przecież z początkiem sierpnia 1877 roku, a pierwszy pociąg do Lublina, z którego skorzystać mogli zwykli śmiertelnicy, odchodził z Pragi Nadwiślańskiej dopiero za... trzy tygodnie ${ }^{28}$.

Były zatem na peronie trzy pięknookie panienki czy ich tam nie było? Wybierały się do Lublina czy po prostu przyszły na stację zwabione zwykłą ciekawością? Miały czy nie miały ze sobą jakieś bagaże? Narrator Michatka jest, jak powiedziałem, opowiadaczem niewiarygodnym, trzymającym się pola widzenia, jakie odsłania się przed niepiśmiennym chłopakiem. Takim, który w Warszawie „upił się parę razy przy świętej niedzieli jak wieprzak” $(580)^{29}$.

27 [rubryka Wiadomości miejscowe], „Kurier Warszawski” 1877 nr 185, z 11 (23) sierpnia.

28 Próbne pociągi (dostępne dla pasażerów) zaczęły kursować od 17 sierpnia (wyjeżdżając z Kowla i Mławy co drugi dzień). Zob. Z. Gardziński Budowa i pierwsze lata funkcjonowania Nadwiślańskiej Kolei Żelaznej w Chełmie (1874-1914), w: Chełm nieznany 2. Tradycje kolejowe Chełma, red. B. Jarosz, PWSZ, Chełm 2009, s. 38-39.

29 Dzień, w którym Michałko ratuje przywalonego murem człowieka, zaczyna się od przyjemnego oszołomienia: „Chwilę postał przed bramą namyślając się, gdzie iść: w lewo czy w prawo? 
Niewiarygodnym narratorem będzie okazywał się subiekt Rzecki, który raz po raz tęgo pociąga. Świat, jaki wyłania się z opowieści trzecioosobowego narratora Lalki, też ma kontury rozmyte. Niby wszystko układa się w nim, jak trzeba, ale już tytuł pierwszego rozdziału przygotowuje czytelnika na... błądzenie. Mowa w nim, przypomnijmy, o tym, , ,jak wygląda firma J. Mincel i S. Wokulski przez szkło butelek"30. Może urocze panienki z Kartek z podróży są częścią świata, który tak kolorowo wyglądał "przez szkło alasza”? Może zatem w Kartkach i w Michatku pisarz wypróbowywał chwyt, który wykorzysta z sukcesem w Lalce? Kompozycyjna otwartość, która ujawni się w pytaniach o los Wokulskiego, zostaje zapowiedziana tajemniczym zniknięciem Michałka: „Rozbiegła się policja, rozbiegli się robotnicy i - nie znaleźli Michałka” (587). Błądzenie w świecie Prusa wcale nie musi brać się z nieznajomości topografii.

Na rogu zobaczył otwarty szynk, więc wstąpił na śniadanie. Wypił duży kielich wódki i weselszy powlókł się w tę stronę, gdzie było widać rusztowania" (584).

Nawiązuje tu wprost do znakomitej interpretacji powieści, którą zaproponował Józef Bachórz. Bachórz pisze: „Zdarzenia fabularne wyłaniają się w «Lalce» metodą, którą pisarz stosował nader konsekwentnie od pierwszych zdań po ostatnie, od tytulatury pierwszego rozdziału, reklamującego się słowami «Jak wygląda firma J. Mincel i S. Wokulski przez szkło butelek», po finalne «Non omnis moriar»". Jest to metoda "«rozchwiania» gruntu, na którym zasadzają się fabuły" (zob. Uwagi o fabule „Lalki”, w: Fabuła utworu literackiego, red. nauk. Cz. Niedzielski, ). Speina, Wydawnictwo UMK, Toruń 1987, s. 29, 33). 


\section{Abstract}

\section{Wojciech Tomasik}

KAZIMIERZ WIELKI UNIVERSITY (BYDGOSZCZ)

Michatko's Wanderings: On the Map of Prus's Warsaw

The fictional events in Prus's novella "Michałko" are set in the real geographical space of Warsaw at a precise historical moment - August and September 1877, i.e. a time of intense construction across the city. Prus experiments with the technique he would later use in The Doll (Lalka), in particular the use of an unreliable narrator. Michałko's wandering and the blurring of the contours of the world represented amount to a method that could be described as'narration through the glass of a bottle'.

\section{Keywords}

realism, unreliable narrator, the geography of literature 